\title{
'Adembenemende contacten....' 'Breathtaking inspirations....'
}

Citation for published version (APA):

Drent, M. (2006). 'Adembenemende contacten....' 'Breathtaking inspirations....'. Universiteit Maastricht. https://doi.org/10.26481/spe.20060512md

Document status and date:

Published: 12/05/2006

DOI:

10.26481/spe.20060512md

Document Version:

Publisher's PDF, also known as Version of record

\section{Please check the document version of this publication:}

- A submitted manuscript is the version of the article upon submission and before peer-review. There can be important differences between the submitted version and the official published version of record.

People interested in the research are advised to contact the author for the final version of the publication, or visit the DOI to the publisher's website.

- The final author version and the galley proof are versions of the publication after peer review.

- The final published version features the final layout of the paper including the volume, issue and page numbers.

Link to publication

\footnotetext{
General rights rights.

- You may freely distribute the URL identifying the publication in the public portal. please follow below link for the End User Agreement:

www.umlib.nl/taverne-license

Take down policy

If you believe that this document breaches copyright please contact us at:

repository@maastrichtuniversity.nl

providing details and we will investigate your claim.
}

Copyright and moral rights for the publications made accessible in the public portal are retained by the authors and/or other copyright owners and it is a condition of accessing publications that users recognise and abide by the legal requirements associated with these

- Users may download and print one copy of any publication from the public portal for the purpose of private study or research.

- You may not further distribute the material or use it for any profit-making activity or commercial gain

If the publication is distributed under the terms of Article $25 \mathrm{fa}$ of the Dutch Copyright Act, indicated by the "Taverne" license above, 



\section{Colofon}

Basisontwerp en realisatie: Datawyse | Universitaire Pers Maastricht Lay-out: Tiny Wouters en Marjon Elfferich

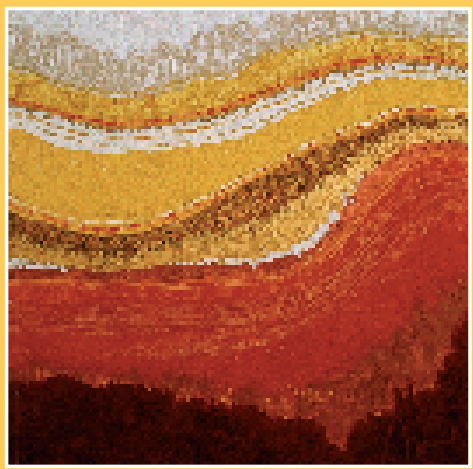

Cover design: detail schilderij

'Water is the Wizard'

(c) Marcelle van Dijck-Heitzer

marcelle.earth-paintings@planet.nl

Illustraties: Fabiano Peltrera

(c) Fabiano Peltrera

f.peltrer@planet.nl

ISBN-10: 90-78076-02-X

ISBN-13: 978-90-78076-02-5

NUR: 870

(c) Marjolein Drent, Maastricht 2006

ildinfo@lung.azm.nl

Alle rechten voorbehouden.

Niets uit deze uitgave mag worden verveelvoudigd, opgeslagen in een geautomatiseerd gegevensbestand of openbaar gemaakt, zonder voorafgaande schriftelijke toestemming van de auteur of uitgever. 


\section{'Adembenemende contacten...'}

'Breathtaking inspirations...' 



\title{
'Adembenemende contacten...' 'Breathtaking inspirations...'
}

\author{
Rede \\ Uitgesproken bij de aanvaarding van het ambt \\ van bijzonder hoogleraar longziekten \\ i.h.b. 'interstitiële longaandoeningen' \\ aan de Universiteit Maastricht, \\ op vrijdag 12 mei 2006 \\ door \\ Dr. Marjolein Drent
}

U

M Universiteit Maastricht

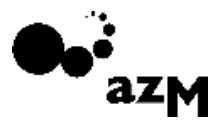





\section{'Adembenemende contacten...'}

Mijnheer de Rector Magnificus, geacht college van bestuur, gewaardeerde collega hoogleraren, collega's uit binnen- en buitenland, medewerkers van het azM, patiënten, familie en vrienden, en alle andere aanwezigen,

Vandaag zal ik officieel het ambt aanvaarden van hoogleraar. Ik beschouw het als een grote eer en enorm voorrecht dat ik mijn inaugurale rede voor $u$ allen mag uitspreken. In deze rede zal $i k$ trachten $u$ op adembenemende wijze kennis te laten maken met het onderwerp van mijn inspirerende leeropdracht 'interstitiële longaandoeningen' en het maatschappelijke en wetenschappelijke belang van deze leerstoel. Samenwerking met allerlei disciplines, waarvan vanmiddag velen aanwezig, is hierbij essentieel. De manier van werken lijkt erg op dat van een detective: uitpluizen en zoeken naar soms onverwachte verbanden.

\section{Contactorgaan}

Allereerst wil ik het begrip contactorgaan en de relatie tussen een contactorgaan en het ontwikkelen van aandoeningen bespreken. Het meest voor de hand liggende en bekende contactorgaan is onze huid. Allerlei stoffen kunnen via de huid het lichaam binnendringen, en soms een ongewenst effect hebben. Echter niet de huid maar de longen vormen ons grootste contact orgaan. De oppervlakte van de huid bedraagt ongeveer $11 / 2 \mathrm{~m}^{2}$. Het oppervlak van de longen is ongeveer $90 \mathrm{~m}^{2}$, ofwel de afmeting van een half tennisveld. Het oppervlak van de longen bedraagt dus ongeveer 60 maal dat van de huid van een mens.

De long is als het ware 'ingebed' in twee omgevingen, die beide schadelijke substanties kunnen aanvoeren. Allereerst is er contact met de omgevingslucht. De functie van de longen is gaswisseling: we ademen lucht in waarin zich zuurstof $\left(\mathrm{O}_{2}\right)$ bevindt, dat wordt opgenomen en koolzuur $\left(\mathrm{CO}_{2}\right)$ wordt weer uitgeademd. 


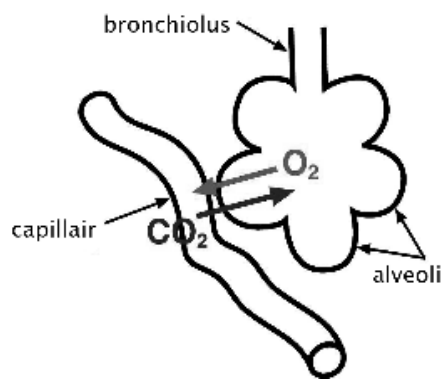

Figuur 1 - Gaswisseling in de long.

Deze gaswisseling vindt plaats in de longblaasjes (alveoli). Zo wordt zuurstofarm bloed wat uit het lichaam komt weer zuurstofrijk (figuur 1). Contact via de longen is minder direct, maar niet zomaar te verhinderen. De lucht die iemand inademt kan letterlijk adembenemend zijn als hier organische of anorganische schadelijke deeltjes of gassen in aanwezig zijn. Daarnaast heeft de long nauw contact met de bloedbaan. Via deze route kunnen ook allerlei schadelijke stoffen de long bereiken en letterlijk tot een adembenemende toestand leiden. Dit zal naast het belang van multidisciplinaire samenwerking de rode draad zijn in mijn verhaal van vanmiddag.

\section{Interstitiële longaandoeningen}

Meest bekende longaandoeningen zijn aandoeningen waarbij mensen moeilijk 'lucht' krijgen en zich benauwd voelen. Er is dan een probleem met de toegangswegen van de long (de takken van de boom), zoals bij astma en COPD (emfyseem). Daarnaast kunnen problemen ontstaan, doordat men met het ademen lucht met deeltjes en/of gassen inademt. Het inademen van bepaalde stoffen zet vervolgens een afweer- of beschermingsmechanisme in gang. Normaal verloopt dit afweerproces zonder grote problemen en wordt de persoon in kwestie niet ziek. Bij 
daarvoor gevoelige personen ontspoort dit proces, treedt een te heftige afweerreactie op en ontstaat er een longafwijking. Bij deze aandoeningen worden vooral het longweefsel zelf aangetast. Men noemt deze ziektebeelden interstitiële ofwel diffuse longaandoeningen. In Nederland lijden naar schatting 20.000 mensen aan één of andere vorm van een dergelijke diffuse longaandoening.

\section{Schadelijke invloeden van buitenaf}

In Limburg zijn diffuse longaandoeningen door adembenemende contacten niet onbekend. ledereen kent de 'zwarte longen' ofwel stoflongen van mijnwerkers. Deze werknemers ademen steenstof in en dat bereikt zo de long. Steenstof bevat silica, een anorganische stof. De longen beschikken over een natuurlijke reinigingsdienst. Deze bestaat uit een leger van stofzuigercellen, die proberen al die stofdeeltjes op te ruimen. Er wordt getracht die deeltjes af te breken ofwel te verteren. Daar ligt het probleem, dat lukt namelijk niet. De cellen sterven af, de volgende generatie probeert hetzelfde. Ook deze cellen zijn daar niet toe instaat. Bij dit proces komen voor de long schadelijke stoffen vrij. Uiteindelijk ontstaan in de long van de betrokken persoon afwijkingen en krijgt hij klachten. Het wordt moeilijker om te ademen en zuurstof op te nemen. Het uithoudingsvermogen neemt af en er kunnen hoestklachten ontstaan. Deze aandoening komt overigens niet alleen bij de mijnwerkers zelf voor, maar ook bij de vrouwen van die mijnwerkers door het wassen van de kleren van hun echtgenoot en/of zonen, ook bij zandstralers, bij glasbewerkers en werkers in de rubberindustrie, etc.

\section{Oorzaak en gevolg}

Mijn interesse is al vroeg uitgegaan naar vragen zoals: 'waarom zijn bepaalde stoffen schadelijk voor de één, maar niet voor de ander?' Wat ligt ten grondslag aan bepaalde afwijkingen vastgesteld bij patiënten, wat is de oorzaak? Soms is het resultaat 
van uitgebreid onderzoek ontoereikend en komt men niet verder dan de aandoening de stempel 'idiopathisch' ofwel oorzaak onbekend op te plakken.

Factoren van invloed bij het ontstaan van een aandoening

- blootstelling

- omstandigheden

- aanleg ofwel erfelijke predispositie

- of een combinatie van dat alles?

Om te bepalen wat de meest geschikte behandeling is voor iemand, is het nodig om te achterhalen wat de mogelijke oorzaak van de ontstane afwijkingen is. Is dat blootstelling aan een voor die persoon schadelijke stof? Heeft het te maken met een aangeboren aanleg tot het ontwikkelen van een bepaalde reactie of met een combinatie van blootstelling en aanleg? Waarom is een specifieke stof schadelijk voor een bepaald persoon? Wat bepaalt of iemand uiteindelijk een ziekte zal ontwikkelen? Misschien op het eerste gezicht vrij eenvoudige vragen, maar om die zorgvuldig te kunnen beantwoorden is nogal wat nodig.

\section{Juiste informatie}

Allereerst is het verhaal van de patiënt erg belangrijk. Om er achter te komen wat iemand mankeert en vooral hoe een bepaalde aandoening kan zijn ontstaan is het van essentieel belang om goed te informeren wat iemand allemaal heeft gedaan. Het volstaat hier niet met een korte anamnese, maar een uitgebreide inventarisatie van mogelijke contacten en blootstellingen is noodzakelijk. Volharding en doorzettingsvermogen van de arts is hier onmisbaar.

Het stellen van de juiste vragen en goed luisteren kunnen behulpzaam zijn bij het ontrafelen van het raadsel. In de praktijk wordt dit nogal eens beïnvloed door tijdsdruk, hierdoor kan 
het doorzettingsvermogen en de tolerantie van de zorgverlener afnemen. Een juiste dosis nieuwsgierigheid is van groot belang. Er dient rekening gehouden te worden met het feit dat de potentiële oorzaak van diffuse longaandoeningen in principe alle deeltjes of stoffen aanwezig in de inademinglucht of het bloed kunnen zijn (figuur 2).

Creativiteit is een voorwaarde om samen met de patiënt mogelijke 'triggers' te identificeren. De manier van werken is vergelijkbaar met dat van een detective. Sherlock Holmes maakte gebruik van de zogenaamde deductiemethode (figuur 3). Dat zal ik nu samen met $u$ onder de loep nemen.

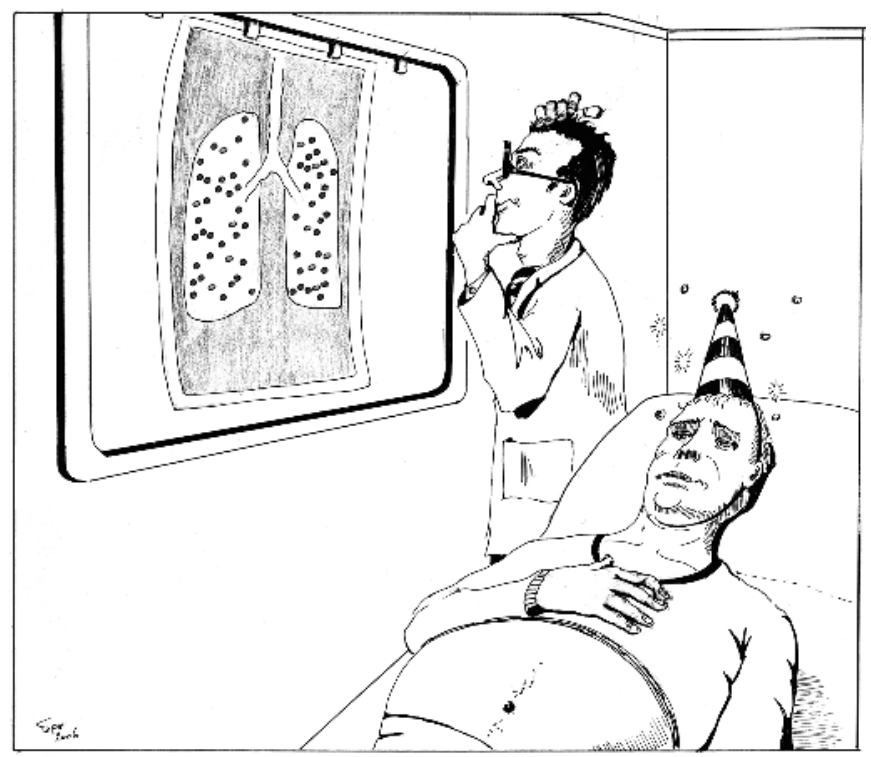

Figuur 2 - Deze man heeft op adembenemende wijze carnaval gevierd. Helaas voor hem is het geëindigd met het ontwikkelen van een zogenaamde 'confettilong'. Deze diffuse interstitiële longaandoening zien we nogal eens bij mensen met als hobby uitbundig feestvieren. (-) 


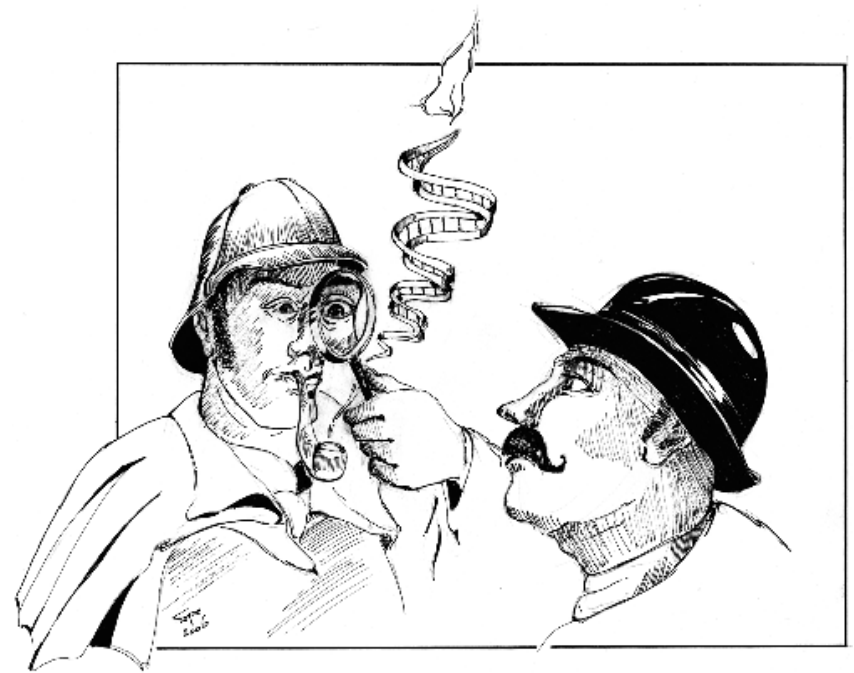

Figuur 3 - Sherlock Holmes, consultant detective, bekend om zijn deductiemethode.

Goede samenwerking tussen verschillende disciplines en bundeling van deskundigheid is noodzakelijk. Een bijkomstig voordeel hiervan is dat de expertise steeds verder kan worden uitgebreid, dat verbanden kunnen worden gelegd waarmee vervolgens weer nieuw wetenschappelijk onderzoek kan worden geïnitieerd. Tevens kan zo de begeleiding van patiënten met dergelijke aandoeningen worden verbeterd. Binnen het azM wordt met allerlei initiatieven, waaronder azMove, sterk gestimuleerd de eilandencultuur te doorbreken en naar maximale soms virtuele samenwerking te streven.

\section{Juiste diagnose}

Het doel van een behandeling is primair het verbeteren van de kwaliteit van leven van de patiënt. Om dat zo optimaal mogelijk te kunnen nastreven is allereerst het stellen van de juiste diagnose van belang. Hiervoor zijn een aantal redenen aan te geven. 
Aanpak probleem van patiënt

1. goede interviewer, die de juiste vragen weet te stellen, en alle mogelijke stoffen waarmee contact is geweest en het medicijngebruik inventariseert

2. klinisch onderzoek:

- laboratoriumonderzoek

- beeldvormende technieken

. radiologie

. nucleaire geneeskunde

- microbiologie

- pathologie

- juiste consulten op indicatie

3. aanvullende specifieke technieken

- elektronenmicroscopie en elementanalyse

- DNA-onderzoek, polymorfismes

4. provocatie

Het zoeken naar mogelijke oorzaken en genetisch verbanden is daarbij essentieel. Voor wetenschappelijk onderzoek, waaronder genetisch onderzoek, is een goede klinische afbakening noodzakelijk. Een duidelijke definitie van het zogenaamde fenotype (de klinische presentatie) is belangrijk voor het kunnen doen van uitspraken over het genotype (de erfelijke aanleg) met behulp van DNA onderzoek.

Belang van de juiste diagnose

- van betekenis voor prognose

- wat staat de betrokken patiënt te wachten?

- contacten trachten te vermijden met mogelijke trigger

- preventiemanagement

- tijdig kunnen starten met de meest optimale behandeling 


\section{Samenwerking}

Door multidisciplinaire, multicentrische, nationale en internationale samenwerking bij de begeleiding van patiënten met interstitiële longaandoeningen kan er veel worden bereikt. Dat moge ook blijken uit resultaten verkregen uit onderzoek mede tot stand gekomen door samenwerking met andere instituten en groepen.

Het is in dat kader enorm toe te juichen dat in Utrecht ook de basis is gelegd het aandachtsgebied interstitiële longaandoeningen serieus te nemen. Onlangs is de jarenlange ervaring op dit terrein van mijn opleider en voorbeeld prof.dr. J.M.M. van den Bosch werkzaam in het Sint Antonius ziekenhuis te Nieuwegein met een leerstoel bekroond. Het verheugt me dan ook dat we de intentie hebben uitgesproken om ons gezamenlijk in te zetten voor interstitiële longaandoeningen in de breedste zin van het woord. Het doel zal zijn een voor Nederland belangrijke positie te verwerven ten aanzien van wetenschappelijk onderzoek en patiëntenzorg.

Samenwerking

- huisartsen

- clinici

- paramedici

- basiswetenschappers

- bedrijfsartsen

- patiëntenverenigingen

- zorgverzekeraars

- industrie

Om de kwaliteit van leven te verbeteren is het vinden van de optimale behandeling van groot belang, maar zo niet nog belangrijker voor de toekomst is het opzetten van een adequaat preventiemanagement. Ook hier geldt bij uitstek het belang van samenwerking tussen clinici, basiswetenschappers, be- 
drijfsartsen, zorgverzekeraars, patiëntenverenigingen, maar ook de industrie. Deze laatste partners zouden nog meer gestimuleerd kunnen worden te investeren in het creëren van een zo optimaal mogelijk werkklimaat voor hun werknemers. Ook zou aandacht gevestigd dienen te worden op de soms onzichtbare risico's voor de afnemers en verwerkers van hun producten. Een goede voorlichting is hierbij van groot belang. Zo kunnen door samenwerking (inter)nationale richtlijnen worden opgesteld en het preventiemanagement worden verbeterd. Hierbij zal optimaal gebruik gemaakt worden van vernieuwende wetenschappelijke ontwikkelingen, zoals DNA onderzoek en geavanceerd contactonderzoek. Met de vergaarde kennis zal vervolgens de meest optimale individuele behandeling worden bepaald. Daarnaast is deze kennis bruikbaar bij de begeleiding van slachtoffers van terrorisme en inhalatietrauma's. Het zal benut worden bij het opzetten van internationale netwerken ter preventie en bestrijding van bioterrorisme.

\section{Oorzaken interstitiële longaandoeningen}

De term interstitiële longaandoeningen (ild) is nogal ingewikkeld en vergt verduidelijking (figuur 4). Diffuse longaandoeningen kunnen onder andere ontstaan ten gevolge van contact met organisch materiaal.

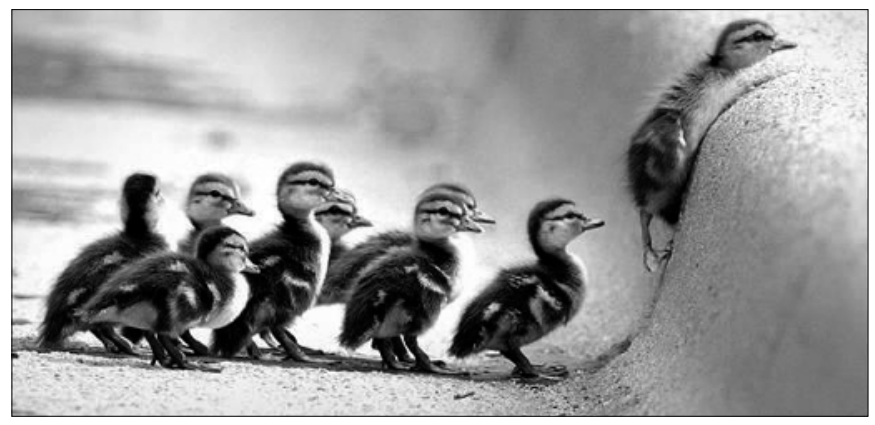

Figuur 4 - ild: 'I love ducklings'. 
Na het inademen van eiwitten of schimmels kunnen sommige personen een soort overgevoeligheidsreactie vertonen, die vervolgens kan leiden tot longafwijkingen.

Een bekend voorbeeld van een dergelijke aandoening is de zogenaamde 'duivenmelkerslong'. Het probleem wordt veroorzaakt door eiwitten in de ontlasting van de vogels. De ontlasting kan tussen de veren van de vogels zitten, maar ook in donzen dekbedden, hoofdkussens en zelfs tussen de veren van opgezette vogels.

Een vergelijkbare reactie kan door schimmels en allerlei medicijnen worden veroorzaakt. Dat het niet altijd eenvoudig is om een dergelijke oorzaak te achterhalen wil ik graag illustreren met een aantal voorbeelden.

\section{Sherlock Holmes: 'Mystery of the pigeon breeder's dog'}

Het eerste voorbeeld betreft een jongen van negen jaar met een zogenaamde 'duivenmelkerslong'. Zijn vader is een beroepsduivenmelker. Zijn ouders verzekerden mij dat hij absoluut geen contact meer had met de duiven en ook niet meer in de hokken kwam. Toen ik nog eens met de jongen sprak over de situatie thuis, vertelde hij dat ze een hond hebben. Hij is gek op die hond en speelt vaak met hem. De hond komt wel in de duivenhokken en ligt daar regelmatig lekker in de zon. De vacht van de hond bevatte ontlastingsresten van de duiven. De jongen aaide en knuffelde de hond regelmatig en zo had hij wel degelijk nog indirect contact met de duiven. Hij was niet allergisch voor de hond, maar in dit geval was de hond de vector van de voor de jongen schadelijke eiwitten.

\section{Sherlock Holmes: 'Case of breathtaking wine'}

Een ander voorbeeld betreft een net gepensioneerde notaris. Hij was de laatste tijd steeds meer benauwd en bleek een laag zuurstofgehalte in het bloed te hebben. Op een röntgenfoto en hoge resolutie CT scan (HRCT) van de longen waren diffuse afwijkingen zichtbaar (figuur 5). Om erachter te komen wat de oorzaak van deze afwijkingen was, werd een longspoeling 

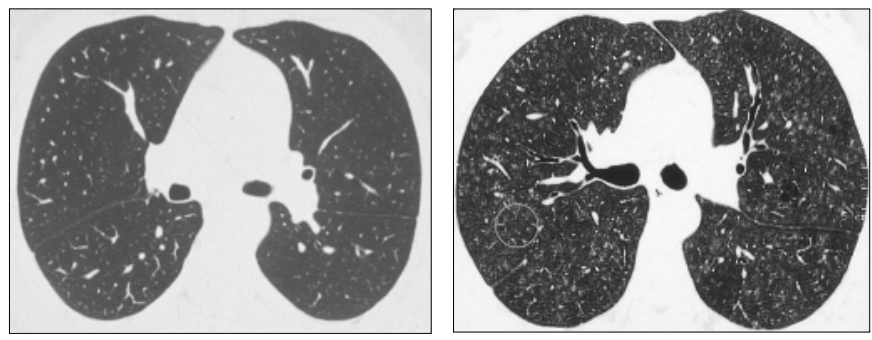

Figuur 5 - Afbeelding van een hoge resolutie CT (HRCT). Links een afbeelding van een normale long, rechts geeft een afbeelding weer van de patiënt. Hierop ziet u duidelijk de zogenaamde 'diffuse' afwijkingen (medische term: 'extrinsieke allergische alveolitis').

verricht (BAL: bronchoalveolaire lavage). Hieruit viel af te leiden dat het beeld op de foto het meest zou kunnen passen bij een allergische reactie veroorzaakt door bijvoorbeeld contact met vogels of schimmels.

De echtgenote van de patiënt werd gevraagd naar een mogelijk verband met iets in huis. We konden geen verklaring vinden. Uiteindelijk heeft een assistent nog eens heel uitgebreid met de patiënt doorgenomen wat hij zoal deed op een dag. Toen vertelde hij dat hij ieder dag voor het avondeten een fles wijn uit de kelder ging halen.

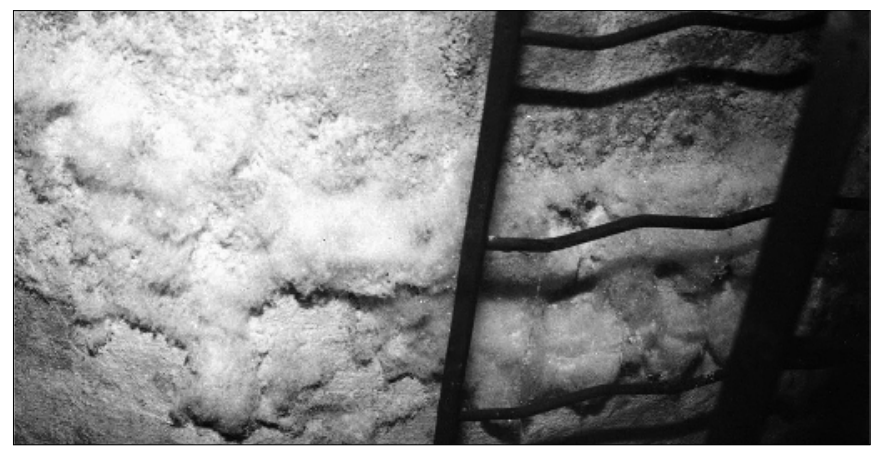

Figuur 6 - Afbeelding van de keldermuur bedekt met schimmel. 
In die kelder bleek de bron van het probleem te liggen (figuur 6). We hebben hier dus te maken met 'adembenemende wijn'. Dit waren twee voorbeelden uit een lange lijst van interessante en opzienbarende observaties waarvan u velen in de literatuur kunt terugvinden.

\section{Wetenschappelijke uitwerking van een observatie}

Het inademen van anorganisch materiaal, zoals het eerder genoemde steenstof, fijnstof, maar ook metalen, aluminium, beryllium, en isolatiemiddelen als steenwol en glaswol, kan in de long tot schadelijke reacties leiden.

\section{Sherlock Holmes: 'Mystery of the fibers'}

Zodra duidelijk is dat iemand met longafwijkingen blootgesteld is geweest aan isolatiemateriaal, zoals glaswol of steenwol, roept dat de volgende vragen op. 'Is die betreffende persoon daar ziek van geworden?' 'Hoe kan men nu met een acceptabele waarschijnlijkheid aantonen dat er een relatie is?' Zijn collega's zijn immers niet ziek. Komt dat doordat de collega's beter de beschermende maatregelen hebben getroffen of reageert de bewuste persoon wellicht op een andere manier? Heeft hij een overactief afweersysteem, waardoor hij ziek wordt?

Om die vragen goed te kunnen beantwoorden dient allereerst te worden aangetoond dat steenwol of glaswol daadwerkelijk in de long is terecht gekomen. Een biopt (stukje longweefsel) wordt daartoe onderzocht met behulp van elektronenmicroscopie en elementanalyse.

Kwalitatieve microanalyse toont een aantal pieken van elementen hierin aanwezig (zie figuur 7a): magnesium, aluminium, en silica. Diezelfde pieken zijn aanwezig in figuur $7 \mathrm{~b}$, maar nu veel sterker, omdat het hier om origineel steenwolmateriaal gaat. Figuur 7c toont een scan van een stukje longweefsel zonder vezels, waar de pieken van deze elementen ontbreken. 


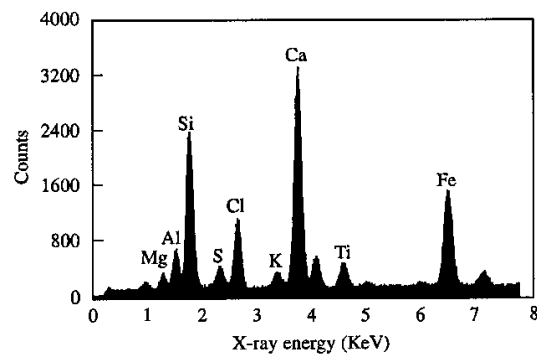

a) scan van een steenwolvezel aangetroffen in de long van een patiënt. Pieken magnesium $(\mathrm{Mg})$, aluminium (Al) en silica (Si).

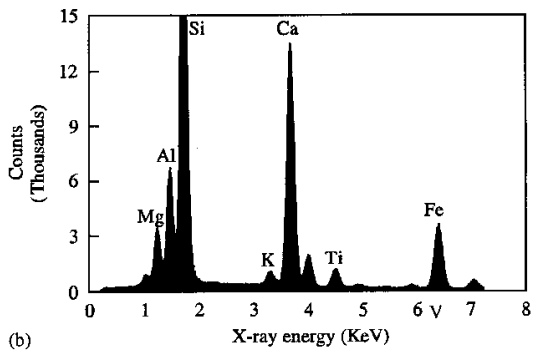

b) scan van een originele steenwolvezel: $\mathrm{Mg}$, Al en Si pieken zijn duidelijk zichtbaar.

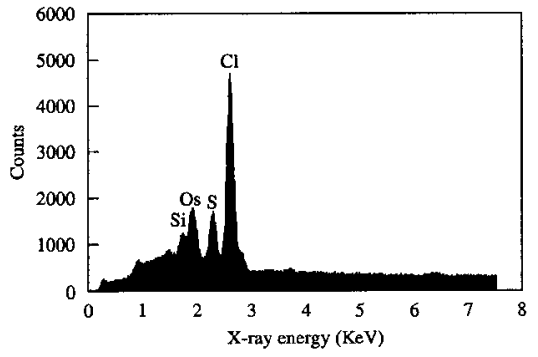

c) een scan van een stukje longweefsel waar geen vezels in zijn aangetroffen, zonder de pieken $\mathrm{Mg}$, Al en Si.

Figuur 7 - Elementanalyse (Respir Med 2000;94:815-20). 


\section{Wetenschappelijke onderbouwing}

De volgende stap is dan proberen aan te tonen dat de zieke persoon anders reageert op contact met steenwol of glaswol dan de niet zieke werknemers. Met andere woorden: onderscheidt de zieke werknemer zich op enigerlei wijze? Is er een genetisch verschil?

Naast genetisch onderzoek met behulp van DNA kunnen we ook provocatietesten doen. Door bloed van een proefpersoon of patiënt bloot te stellen aan een bepaalde stof, bijvoorbeeld glaswol, kan men door het meten van de sterkte van de reactie op deze blootstelling vaststellen of iemand heftiger of anders reageert dan een gezond persoon. Op deze manier wordt een observatie in de praktijk - namelijk de blootstelling aan een bepaalde stof - uitgewerkt tot een hypothese en testmethodes worden ontwikkeld om deze veronderstelling te toetsen.

Om deze route tot stand te kunnen brengen is een goede samenwerking tussen klinische en zogenaamde basiswetenschappers essentieel. Bovendien werkt het ook stimulerend wanneer wetenschappers weten waarom ze een bepaalde test ontwikkelen en de clinici op hun beurt op de hoogte zijn van de mogelijkheden. Dit lijkt voor de hand liggend, maar kan nog veel meer gestimuleerd worden en vormt een belangrijk onderdeel van de zogenaamde 'translational medicine'.

\section{Educatieve functie}

Als een bepaalde zaak is opgelost, is het belangrijk het verhaal uit te werken en op te schrijven in de vorm van een case-report ofwel casuïstieke mededeling en vervolgens aan te bieden aan een wetenschappelijk tijdschrift. Op deze manier kunnen andere collega's kennis nemen van deze bijzondere observatie en dat kan vervolgens motiveren om ook eens aan die mogelijkheid te denken. De klinische impact van zo'n voorbeeld kan enorm zijn echter wetenschappelijk 'scoort' dit niet. Sterker nog, tegenwoordig raadt men van hoger hand af om jonge onderzoekers en artsen te stimuleren een dergelijke observatie zorgvuldig uit 
te werken en te rapporteren. Als reden voor dit advies wordt gegeven dat de impactfactor te laag is. Op deze wijze wordt mijns inziens jonge enthousiaste artsen en onderzoekers een unieke kans om kennis te maken met het zorgvuldig uitwerken en rapporteren van een belangrijke observatie ontnomen. Ook zou deze ervaring interesse in het verrichten van wetenschappelijk onderzoek kunnen aanwakkeren. Dit ontmoedigingsbeleid is bovendien een minachting van de waarde van klinische observaties.

Het huidige waarderingssysteem van belangrijke klinische observaties aan de ene kant en onderzoeksresultaten aan de andere kant zou nog eens kritisch onder de loep genomen moeten worden. Deze situatie is vergelijkbaar met de sportwereld. Als de lat direct te hoog gelegd wordt, ontneem je sporters de motivatie om zich te ontwikkelen tot topsporter. Voor het leveren van een topprestatie heb je naast talent een goede coach nodig, die je behoedt voor overbelasting. Een juiste opbouw is hier cruciaal.

\section{Maatschappelijke relevantie}

Nog steeds ondervinden we de gevolgen van blootstelling aan asbest. Veel mensen hebben in het verleden bewust of onbewust contact gehad met dit isolatiemiddel. Door allerlei beschermende maatregelen is momenteel directe blootstelling vrijwel nihil. Toch zullen artsen ook nu nog steeds geconfronteerd worden met onbegrepen diffuse of andere longafwijkingen waar expositie in het verleden wellicht een rol gespeeld heeft.

Als wordt vastgesteld dat de relatie tussen de ziekte en blootstelling aannemelijk is, is het verstrekken van goede informatie van groot belang. Er dient een goede samenwerking te zijn met bedrijfsartsen, keuringsartsen en huisartsen. Tevens spelen de producent van deze producten en de afnemers een belangrijke rol. Als deze partijen als partners worden gezien in onderzoek en zij ook bereid zijn te investeren in onderzoek, zal zowel het bedrijfsleven als de gezondheidszorg hiervan kunnen profite- 


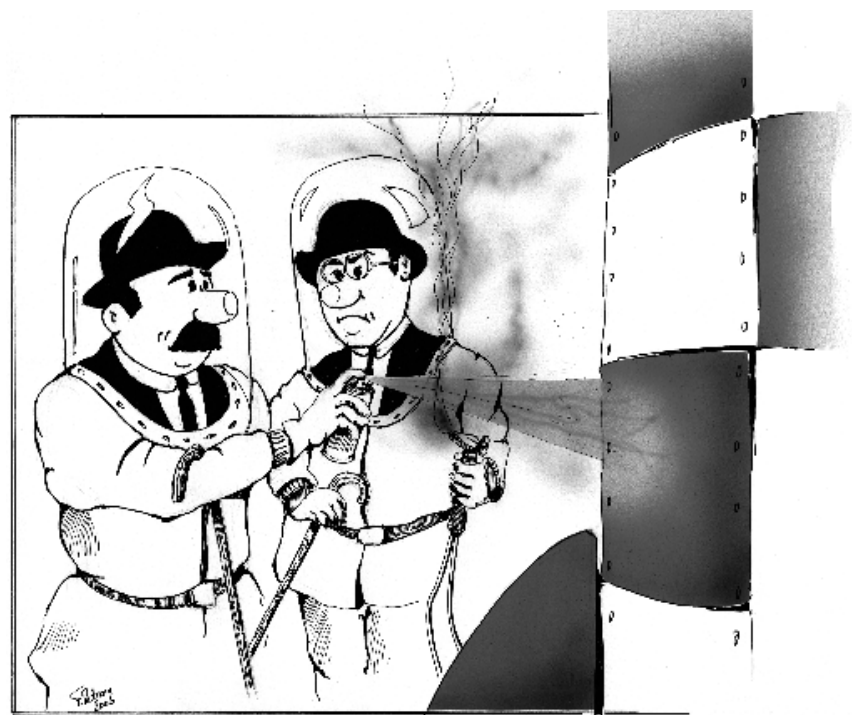

Figuur 8 - Beschermende pakken zijn bij bepaalde beroepen noodzakelijk om de luchtwegen van werknemers te beschermen.

ren. Bundeling van kennis, genereren van financiële middelen en ontwikkeling van de juiste preventieve maatregelen vergt ook hier een nauwe samenwerking. Zo kan het bedrijfsleven een belangrijke rol vervullen in innovatieve ontwikkelingen binnen de gezondheidszorg. Deze ontwikkelingen kunnen bovendien leiden tot betere werkomstandigheden van werknemers en het preventiemanagement verbeteren (figuur 8).

\section{Sarcoïdose}

Een volgende aandoening waar ik graag aandacht voor wil vragen is sarcoïdose. Dat is een grillige aandoening. De oorzaak is nog steeds niet bekend. Er is veel onderzoek aan besteed, maar er valt nog zeer veel te ontdekken. Het is een ziekte die zich overal in het lichaam kan manifesteren. Het komt over de hele 
wereld en bij alle rassen voor. Er is verschil in ernst en verloop. Bij negroïde mensen is het verloop vaak ernstiger. In Nederland lijden naar schatting zo'n 7000 mensen aan sarcoïdose. Goed epidemiologisch onderzoek ontbreekt echter. Om mensen met een aandoening als sarcoïdose goed te kunnen behandelen is het van belang te weten wat deze aandoening bij de betrokkene voor gevolgen heeft. 'Wat is de impact op de kwaliteit van leven?' 'Waar hebben deze mensen hulp bij nodig?' Voor behandelaars is het belangrijk dat ze op de hoogte zijn van de problemen waar patiënten mee worstelen. Dit kan leiden tot meer begrip en adequate behandeladviezen.

In Maastricht is in $\mathbf{2 0 0 0}$ het Sarcoïdose Management Team opgericht. Dit team bestaat uit vertegenwoordigers van allerlei disciplines. Een zo adequaat mogelijke begeleiding van patiënten met sarcoïdose, het bieden van zorg op maat en topreferente zorg vormen de belangrijkste doelen van deze samenwerking binnen het azM. In het in oprichting zijnde ild care centrum zal deze vruchtbare samenwerking worden benut voor patiënten met systeemaandoeningen en andere interstitiële longaandoeningen.

\section{Sherlock Holmes: 'Case of the killing fatigue'}

Uit het onderzoek van Ruth Wirnsberger uitgevoerd in samenwerking met de Sarcoïdose Belangenvereniging Nederland kwam naar voren wat we al wisten uit de verhalen van de patiënten, namelijk dat moeheid een enorme impact op het leven van sarcoïdosepatiënten heeft. Het betreft hier geen gewone moeheid, die we allemaal wel kennen als we te druk zijn geweest, te laat naar bed zijn gegaan, teveel afspraken hebben gemaakt, last van jetlag hebben en ga zo maar door... Het gaat om een alles beheersende moeheid die zoveel invloed op iemands leven kan hebben dat normaal functioneren niet mogelijk is en dagelijkse werkzaamheden te zwaar zijn. De creativiteit wordt afgeremd, eigenzinnige karakters worden aan banden gelegd en talent kan niet optimaal worden benut. Het zorgt voor per- 
soonlijke drama's en kan grote sociale en financiële problemen veroorzaken.

Mijn eerste 'wetenschappelijke' publicatie betrof een reactie op een artikel van prof. van Rood over de invloed van stress op immuniteit en het grote belang van multidisciplinair onderzoek. Hierin werd ingegaan op de grote invloed van allerlei prikkels op het functioneren van het immuunsysteem. Later zou ik worden geconfronteerd met de invloed en impact hiervan bij sarcoïdosepatiënten. Een alles beheersende moeheid kan het gevolg zijn van een overbelast, te actief functionerend immuunsysteem.

\section{Observatie in de praktijk: moeheid}

Moeheid is een vaag begrip. Hoe stel je vast dat iemand moe is? Hoe kun je bepalen wat de invloed van moeheid is op het wel of niet goed kunnen functioneren?

Er is tot op heden geen goede maat om moeheid vast te leggen. Dit is niet gelukt met longfunctieonderzoek, noch met

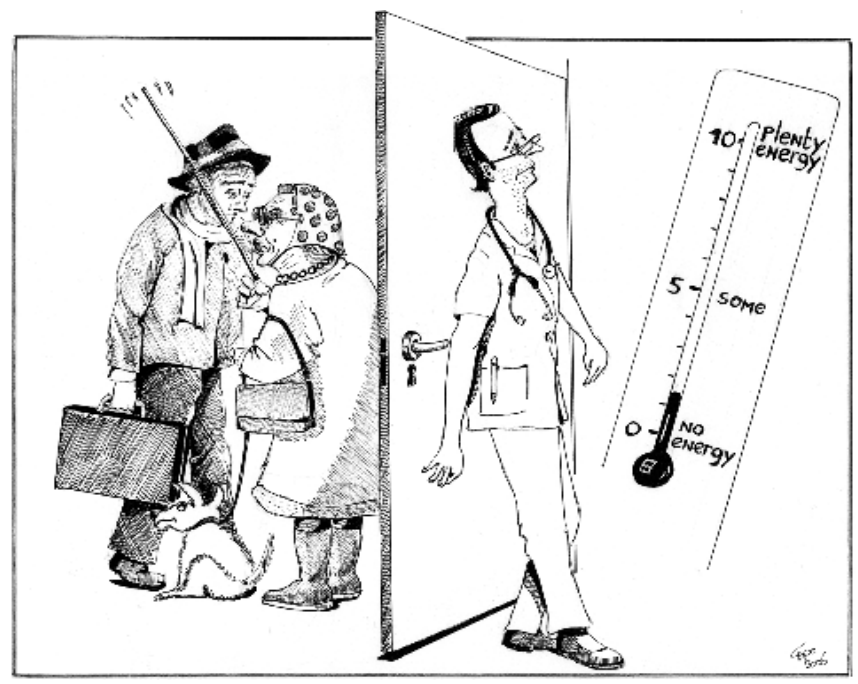

Figuur 9 - Fatigu-o-meter ofwel moeheidmeter, geeft aan hoeveel energiereserve iemand heeft. 
bloedonderzoek of andere testen. Een bijkomstig probleem is dat de patiënten er meestal niet ziek uitzien en veelal worden ze door hun omgeving en werkgevers niet serieus genomen. Moeheid is iets vaags, iets ongrijpbaars en tot op heden bestaat er geen goede 'moeheid' meter (figuur 9).

Voor mensen die sarcoïdose hebben is het erg van belang dat voor moeheid een verklaring wordt gevonden en een betrouwbare meetmethode wordt ontwikkeld. Bij medische keuringen is het belangrijk om met afwijkende getallen te komen, die je kunt afzetten tegen normale waarden. Ons toekomstig onderzoek zal zich hierop richten.

\section{Observatie in de praktijk: vage klachten}

Bij sarcoïdose veroorzaken allerlei stoffen vrijkomend uit granulomen, ofwel ophopingen van afweercellen, ontstekingachtige reacties in het lichaam. Deze stoffen kunnen leiden tot vermindering van de spierfunctie. Het uithoudingsvermogen neemt sterk af en er kunnen allerlei vage klachten ontstaan, zoals pijn en onrustige benen (restless legs). Soms treden ook eetstoornissen op. Deze vage klachten worden keer op keer genoemd door patiënten die zich melden op de polikliniek. Dit bleek geen toeval, maar er was sprake van een steeds terugkerend patroon. Overleg met de neurologen leverde eerst niet veel op, maar uiteindelijk kwamen een aantal patiënten bij Elske Hoitsma terecht. Zij herkende het klachtenpatroon dat past bij een dunne vezel neuropathie.

Het zenuwstelsel beschikt over verschillende aansturingsystemen. De dikke- ofwel willekeurige vezels zorgen voor de motoriek. De zogenaamde dunne- ofwel onwillekeurige zenuwvezels zijn onder andere betrokken bij het ervaren van pijn, de temperatuurszin en de regulering van de bloeddruk. Als hier een stoornis in ontstaan is, spreekt men van een autonome disfunctie. Dit laatste verklaart voor een deel de nogal vage klachten waaronder ook de moeheid te rekenen valt. Doordat zij geen genoegen nam met een standaard antwoord en bereid was af 
te wijken van de norm, was Elske Hoitsma instaat samen met de patiënten en leden van het Sarcoïdose Management Team een ontdekking te doen die grote klinische en wetenschappelijke impact bleek te hebben getuige ook de aandacht in de internationale wetenschappelijke wereld. Deze observatie is mede tot stand kunnen komen door een nauwe samenwerking tussen de afdeling longziekten, neurologie en klinische neurofysiologie.

\section{Wetenschappelijke onderbouwing}

Er is een heel actief internationaal netwerk. Prof.dr. Gerry James nam het initiatief om de WASOG (World Association of Sarcoidosis and Other Granulomatous Disorders) op te richten. Deze wereldorganisatie houdt zich onder andere bezig met het samenbrengen en informeren van collega's over sarcoïdose en gerelateerde aandoeningen, opstellen van richtlijnen, het organiseren van wereldcongressen en heeft ook een verdienstelijk tijdschrift.

In 1958 organiseerde prof.dr. G. James in London het eerste wereldcongres over sarcoïdose. Van hem kreeg ik een uitda-

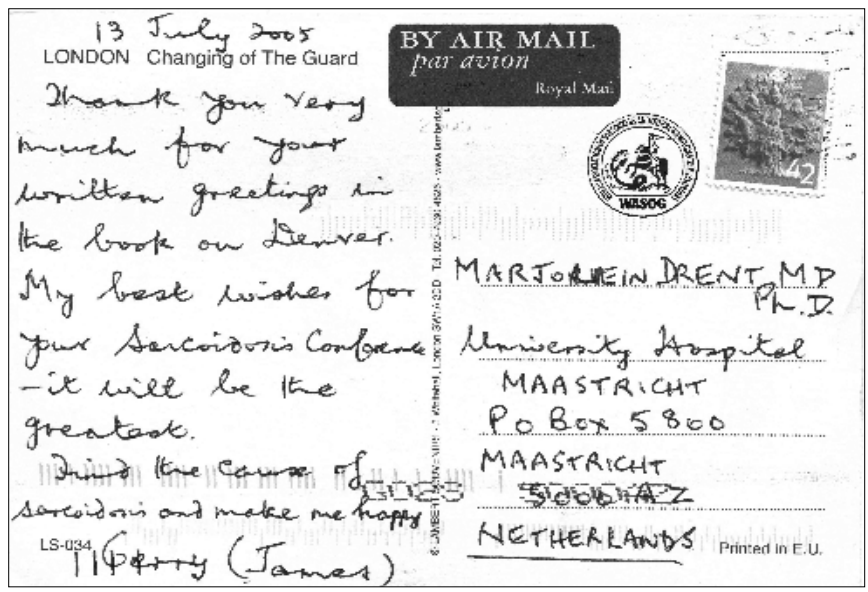

Figuur 10 - Wetenschappelijke opdracht van prof.dr. Gerry James, grondlegger van de WASOG. 
gende wetenschappelijke opdracht, namelijk het vinden van de oorzaak van sarcoïdose (figuur 10).

Door eigen onderzoek zijn we op het spoor gekomen dat het autonome ofwel onwillekeurige zenuwstelsel regelmatig is aangetast bij sarcoïdosepatiënten en patiënten met andere aandoeningen waarbij het afweersysteem is betrokken. Dat verklaart voor een groot deel de vage klachten. De basis ligt dan weer bij de inflammatie ofwel ontstekingachtige reactie optredend bij sarcoïdose en andere ziekten van het afweersysteem. Deze bevinding geeft een nieuwe impuls aan onderzoek naar het vinden van adequate behandelingen.

\section{Maatschappelijke impact}

Deze vaststelling is van groot maatschappelijk belang aangezien sarcoïdose over het algemeen bij relatief jonge mensen voorkomt. Helaas leidt deze ziekte nogal eens tot langdurig

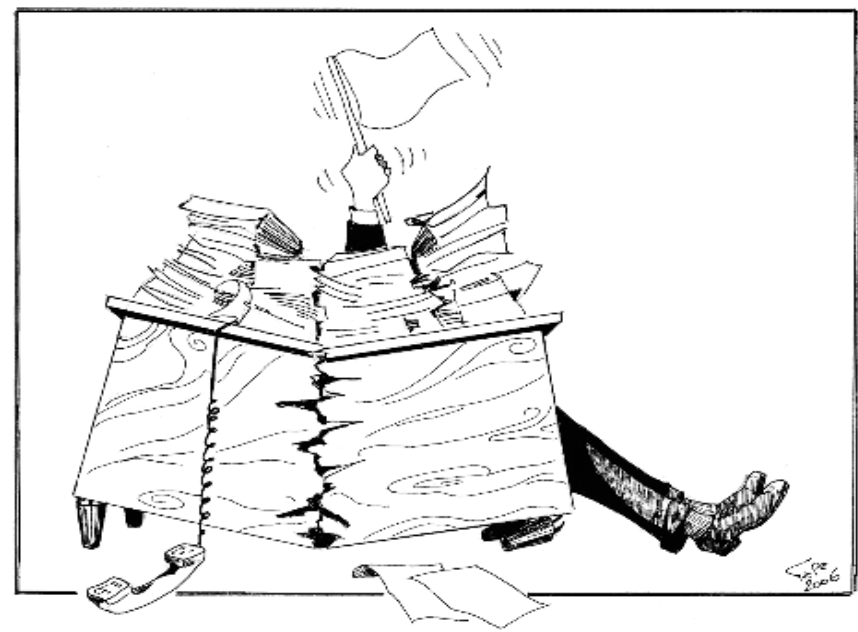

Figuur 11 - Het probleem van deze tijd: stress op het werk. Uit recent onderzoek blijkt zelfs dat het zogenaamde 'sick buildings syndrome' niet het gevolg is van een slecht gebouw, maar van stress en werkdruk (Occup Environ Med 2006; 63: 283-9). 
ongewenst ziekteverzuim. Als een patiënt vervolgens aan de keuringsarts meldt dat hij of zij moe is, te moe is om te werken, krijgt men nogal eens het antwoord 'iedereen is wel eens moe'. Kortom ze stuiten regelmatig op onbegrip en moeten zich constant verdedigen. Dit is niet alleen vervelend, maar dergelijke stress draagt bovendien niet bij aan het herstel (figuur 11). Begrip van hun omgeving en vooral erkenning van het probleem is erg belangrijk voor het genezingsproces. Bovendien is het van belang dat patiënten zelf leren omgaan met het ziek zijn en de beperkingen leren accepteren. Het is namelijk niet altijd mogelijk de aandoening adequaat te behandelen.

\section{Adembenemende geneesmiddelen}

$\mathrm{Na}$ het bespreken van een aantal externe oorzaken met adembenemende gevolgen, wil ik nu aandacht schenken aan mogelijke schadelijke gevolgen van stoffen die de longen van binnenuit via de bloedsomloop bereiken.

In de geneeskunde hebben we de beschikking over vele geneesmiddelen. Veelal hebben patiënten meer dan één aandoening, waardoor verschillende medicamenten tegelijkertijd nodig zijn. Naast het beoogde effect hebben medicijnen ook bijwerkingen. Soms werken ze elkaar tegen, in andere gevallen kunnen ze elkaars effecten versterken. Het Farmacotherapeutisch Kompas en de bijsluiters staan hier vol mee.

Binnen longziekten kennen we ook de zogenaamde 'druginduced' ofwel door medicijnen veroorzaakte toxische longreacties. Hierbij treedt een reactie op in het longweefsel (longparenchym), waardoor het moeilijker wordt om zuurstof op te nemen. Qua presentatie lijkt dit sterk op de voorbeelden die ik net heb besproken. Ook medicijnen kunnen adembenemende gevolgen hebben. Het aantal medicijnen dat voor de long schadelijke effecten kan bewerkstelligen groeit iedere dag. De reden hiervoor is voornamelijk dat men de laatste tijd meer alert is om de link te leggen. Hier geldt bij uitstek dat het belangrijk is om bijzondere observaties te melden en te beschrijven om zo 
anderen op de hoogte te stellen van mogelijke - nog niet eerder beschreven - bijwerkingen.

\section{Bijwerkingen geneesmiddelen in een breder perspectief}

Elke dag sterven gemiddeld tien mensen ten gevolge van bijwerkingen van medicijnen en daarvan is de helft vermijdbaar. Dat blijkt uit een onderzoek van het VARA/NPS programma Zembla dat vorig jaar uitgezonden is. Jaarlijks overlijden in Nederland totaal naar schatting 3500 tot 4000 mensen door bijwerkingen van allerlei geneesmiddelen.

Veel wordt gedaan aan een evaluatie van eventuele bijwerkingen, voordat medicijnen toelaatbaar worden geacht voor gebruik in de praktijk. Weinig onderzoek wordt echter gedaan naar het mogelijke effect van gebruik van meerdere medicamenten tegelijkertijd.

De farmaceutische bedrijven investeren voornamelijk in de bijwerkingen van het product wat zij leveren. Onvoldoende wordt meegewogen dat patiënten vaak meerdere aandoeningen hebben en dus ook meerdere medicamenten gebruiken. Deze medicijnen kunnen elkaar beïnvloeden en uiteindelijk een toxisch effect bij de patiënt veroorzaken. Bij het bepalen of een middel veilig is voor een patiënt, zou in de toekomst meer aandacht besteed dienen te worden aan het effect van het gebruik van combinaties van middelen. Een nauwe samenwerking tussen artsen en apothekers is hier van groot belang. Maar ook de farmaceutische industrie zou dit ter harte kunnen nemen en overwegen meer energie te stoppen in samenwerking dan elkaar aftroeven met veelal vergelijkbare producten. Ook dit zou veel financiële middelen kunnen vrijmaken en tot herstructurering van development strategieën kunnen leiden.

\section{Wetenschappelijke onderbouwing}

Waarom reageert de ene persoon op bepaalde prikkels zoals eerder geïllustreerd, of een bepaald medicijn, of een combinatie van medicijnen met een toxische reactie in de long of elders en 
de ander niet? Wat ligt daaraan ten grondslag? Is het mogelijk om vooraf te voorspellen of iemand een risico loopt om een dergelijke reactie te krijgen? Maar, zoniet belangrijker, is deze reactie te voorkomen?

Om te begrijpen waarom een bepaald geneesmiddel schadelijk kan zijn is het belangrijk de samenstelling te weten en hoe het medicijn in het lichaam wordt afgebroken (geklaard). Sommige medicijnen worden afgevoerd via de nieren (een goede werking van de nieren is dan essentieel). Andere medicijnen worden door bepaalde enzymen in de lever afgebroken.

Tot deze enzymen behoren de zogenaamde cytochroom P450 (CYP 450) enzymen. Deze enzymen zijn instaat medicijnen af te breken. Bij de meeste mensen worden geneesmiddelen gewoon netjes afgebroken zonder dat er problemen ontstaan. Er zijn ook mensen bij wie het systeem wat trager werkt, waardoor het langer duurt alvorens het medicijn wordt afgebroken. Indien hier sprake van is zou je problemen kunnen voorkomen door de tijd tussen inname van de medicijnen te verlengen. Ook zijn er mensen bij wie het systeem snel overbelast raakt. In dat geval kan er sprake zijn van een erfelijk defect, bijvoorbeeld een CYP 450 polymorfisme.

We kunnen dit onderzoeken met behulp van genetisch materiaal: DNA. Om te kunnen verklaren waarom de één wel ziek wordt na contact met een bepaalde stof en de ander niet, kan men bijvoorbeeld zoeken naar het bestaan van polymorfismes. In Nederland hebben naar schatting 20 procent van de mensen één of andere vorm van een dergelijk polymorfisme en een verhoogde kans op afwijkingen.

\section{Sherlock Holmes: 'Mystery of the human DNA'}

Het menselijk DNA kunt u zich voorstellen als een boek. Dit boek heeft 23 hoofdstukken (figuur 12).

Een gen kunt u vergelijken met een alinea. Een gen codeert voor één eiwit, dat wil zeggen beschrijft de samenstelling van een 


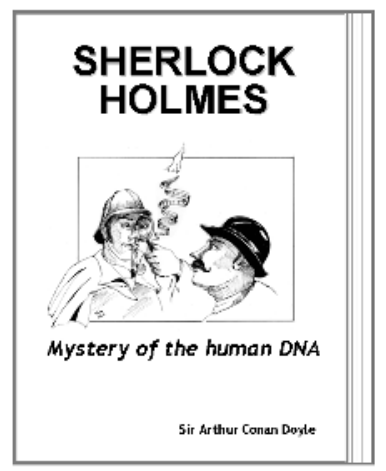

Figuur 12 - Mystery of the human DNA.

eiwit. Een mutatie of polymorfisme ontstaat als een woord fout geschreven is of ontbreekt of is toegevoegd.

Een puntmutatie ontstaat als een letter ontbreekt of een andere letter voor een bepaalde letter in de plaats komt. De weergave is niet meer zoals bedoeld en de betekenis van het woord niet meer duidelijk. $U$ kent allemaal wellicht het probleem dat ontstaat als je een typefout maakt in een e-mail adres. Je wordt er direct op gewezen aangezien de server aangeeft dat de mail niet te bezorgen is en je krijgt je bericht onmiddellijk terug!

\section{Monitoring in de praktijk}

Als een persoon een defect in het afbraaksysteem van bepaalde medicijnen heeft, veroorzaakt dat een sterk verhoogd risico op het ontwikkelen van schadelijke bijwerkingen. In dat geval is het dan ook af te raden om deze medicijnen voor te schrijven (figuur 13). In de praktijk wordt hier vreemd genoeg nog weinig gebruik van gemaakt.

In 1993 verscheen in het Nederlands Tijdschrift voor Geneeskunde een artikel getiteld: 'Psychische klachten door een overdosering van theofylline; noodzakelijkheid van spiegelcontrole.' Het artikel beschrijft twee patiënten met beiden een duidelijke theofyllineintoxicatie met ernstige klinische gevolgen. Dit benadrukte nog eens het belang van zorgvuldige dosering van 
Patiènten met gelijke dlagnose

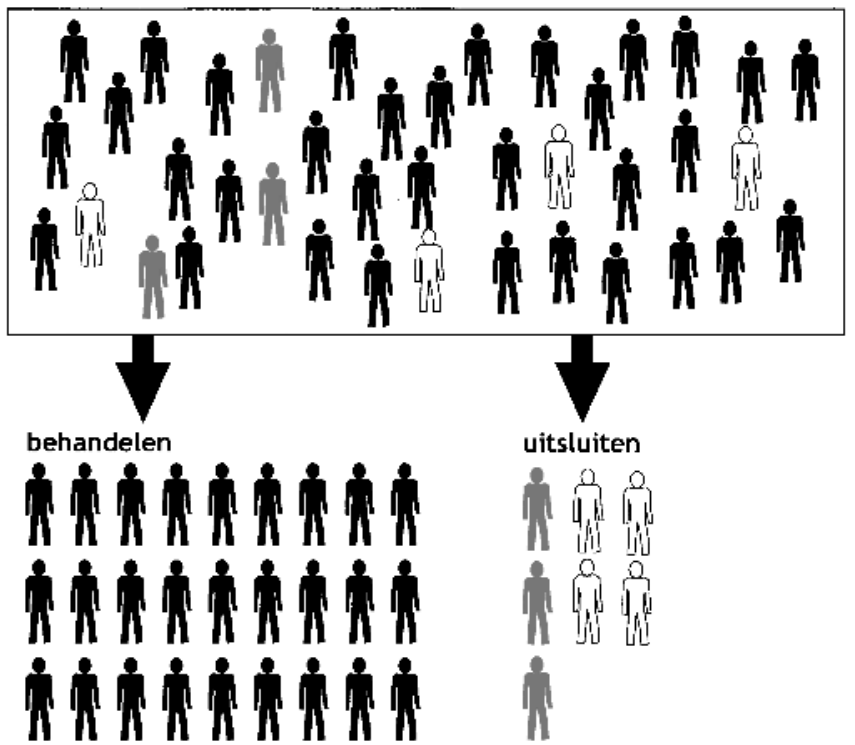

Patiënten zonder predispositie voor het ontwikkelen van een toxische reactie en goed reagerend.

Patiënten onvoldoende reagerend of mensen reagerend met toxische reacties.

\section{GCCCACCTC}

\section{GCCCGCCTC}

Figuur 13 - Farmacogenomische kennis toegepast in de medische praktijk. Het is van belang de mensen die reageren op een bepaald geneesmiddel met de gewenste reactie te kunnen onderscheiden van degenen die reageren met een toxische reactie of niet reageren (Ann Rev Pharmacol Toxicol 2001;41:101-21).

theofylline met inachtneming van een aantal factoren, welke de serumspiegel beïnvloeden, en regelmatig controle van de serumspiegel. Spiegelbepaling is namelijk noodzakelijk vanwege de grote individuele verschillen in farmacokinetiek, de kleine marge tussen de toxische en therapeutische spiegel, en de ernstige bijwerkingen. Het metabolisme van theofylline is mede afhankelijk van cytochroom P450 enzymen. Een sterke afname 
van vooral de arteriële leverdoorbloeding, zoals kan optreden bij hartfalen met als gevolg leverischemie, heeft ook nog een vermindering van de werkzaamheid van het cytochroom P450 systeem tot gevolg. Bovendien kunnen bij het toedienen van een combinatie van geneesmiddelen andere effecten optreden dan bij toediening van ieder middel afzonderlijk. In 1993 hadden we nog niet de beschikking over de techniek om aan te tonen of er wellicht een stoornis bestond in het afbraaksysteem van theofylline bij deze patiënten.

Ik bleef geboeid door de vraag: 'hoe komt het nu dat de ene persoon een toxische, schadelijke reactie krijgt na inname van een bepaald geneesmiddel, een grote groep op de normale en gewenste manier reageert en een ander niet of nauwelijks een effect ondervindt?'

Inmiddels weten we meer over de invloed van aanleg op het verwerken van medicijnen en vooral het mogelijk ontwikkelen van bijwerkingen.

\section{Toekomstperspectief}

Door vooraf te bepalen of het afbraaksysteem wel voor de volle 100 procent functioneert of minder goed, kan veel leed voorkomen worden. Met deze kennis kan vooraf het juiste doseringsadvies gegeven worden. Bij de twee beschreven patiënten had een langdurige en kostbare ziekenhuisopname voorkomen kunnen worden.

In het azM is een CYP (cytochroom P450) werkgroep opgericht. Deze werkgroep begeleid artsen bij het voorschrijven van de juiste dosis en combinatie van medicijnen. Het doel is dat we de mensen die we medicijnen voorschrijven ook daadwerkelijk adequaat behandelen. We trachten voordat de medicijnen worden voorgeschreven te voorspellen welke personen een verhoogde kans hebben op het ontwikkelen van bijwerkingen.

In de toekomst zal het mogelijk zijn dat iemand een chipkaart heeft met zijn/haar DNA-profiel (genetisch paspoort: link met vingerafdruk). 
Nadat de gegevens van het genetisch paspoort in een geavanceerd computerprogramma zijn ingevoerd wordt haarfijn aangegeven welke dosering van medicijnen veilig is voor die persoon, hoe te handelen bij combinatietherapie (n.b. erg belangrijk aangezien het in de meeste gevallen niet aan één bepaald medicament ligt!) en welke medicatie vermeden dient te worden.

Er is al een heel praktische website operationeel welke deze service verleent. Deze informatie is niet nieuw echter het is vooral bekend bij basiswetenschappers en niet-clinici. Hier geldt bij uitstek dat een bundeling van de kennis door middel

Checklist voor het beoordelen van potentiële rol voor farmacogenetica in het reduceren van bijwerkingen van geneesmiddelen:

- beschouw ieder medicament als een potentiële veroorzaker van bijwerkingen

- controleer of het geneesmiddel door een polymorfisch enzym wordt gemetaboliseerd

$\mathrm{Nb}$ : het voorkomen van polymorfismes varieert substantieel per ras

- houdt vooral rekening met het feit dat het probleem zich vooral kan voordoen ingeval van het voorschrijven van 2 of meer medicijnen tegelijkertijd, die worden gemetaboliseerd door hetzelfde enzym

- overweeg spiegelcontrole bij medicamenten waar bijwerkingen van zijn te verwachten

Nabije toekomst:

- specifiekere preventie bijwerkingen geneesmiddelen

- genotypering voorafgaande aan het voorschrijven van geneesmiddelen

- zorgvuldig individueel doseringsadvies gebaseerd op de uitslag van de genotypering en het medicijnmetabolisme, vooral bij combinatietherapie 
van samenwerking tussen clinici en niet-clinici en het overdragen van nuttige kennis tot een efficiëntere en voor de patiënt veiliger behandelplan leidt.

Dit lijkt misschien ver weg, doch dit is dichter bij dan wij denken. Binnen een aantal jaren zal genotypering worden benut bij het samenstellen van een uniek genetisch paspoort en worden gebruikt bij het op maat voorschrijven van medicijnen in de dagelijkse praktijk.

\section{Maatschappelijke relevantie}

De integratie van deze technische mogelijkheden in de begeleiding van chronisch zieke patiënten kan enorm veel leed en kosten besparen. Onlangs verscheen een onderzoek waarin beweerd werd dat ongeveer $30 \%$ van de ziekenhuisopnames te maken heeft met verkeerd medicijngebruik. Een deel daarvan wordt ingenomen door patiënten met longafwijkingen. Voor deze adembenemende contacten geldt bij uitstek: 'voorkomen is beter dan genezen'. Ook hier is er een belangrijke plaats voor preventiemanagement.

\section{Toekomstig onderzoek}

Voor erkenning van een probleem dient men eerst een goede definitie van het probleem te formuleren. Om tot een goede definitie te kunnen komen zijn adequate meetmethodes noodzakelijk. Toekomstig onderzoek zal bestaan uit het zoeken naar nieuwe meetmethodes om de problemen van patiënten beter te kunnen vastleggen.

De overreactie van het natuurlijke afweersysteem dient te worden gereguleerd en te worden afgeremd. Hierbij is het van belang de oorzaak van deze overreactie te achterhalen en - indien mogelijk - te elimineren.

Dit is echter niet altijd voldoende. Soms betreft het stoffen die het lichaam niet kan afbreken, zoals aluminium en de eerder genoemde isolatiematerialen asbest, steenwol en glaswol (figuur 14). Deze stoffen blijven na inademing in het lichaam 


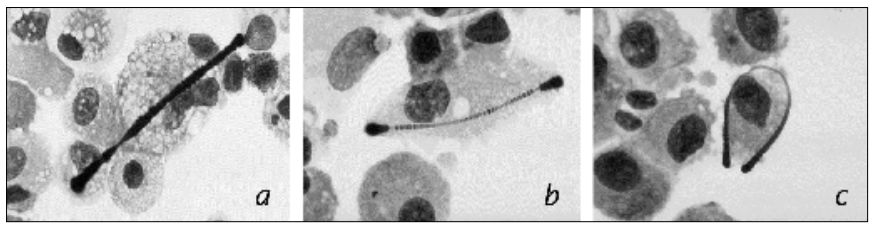

Figuur 14 - Strijd tussen een asbestvezel en een alveolaire macrofaag (AM, ofwel opruimcel aanwezig in de long). De afgebeelde cellen en vezels zijn aangetroffen in bronchoalveolaire lavage (BAL) vloeistof verkregen door middel van een zogenaamde longspoeling. a) asbestvezel in de buurt van een $A M, b$ ) de $A M$ probeert de asbestvezel te vernietigen, c) wie heeft er nu gewonnen: de $A M$ of de vezel?

aanwezig en vormen een continue stoorzender. Deze vezels kunnen allerlei schadelijke reacties teweegbrengen, voor het lichaam schadelijke stoffen doen vrijkomen en tot oxidatieve stress leiden. In dit geval is er behoefte aan voedingsmiddelen en medicijnen, die instaat zijn om de schadelijke reacties in het lichaam te onderdrukken. Dit maakt dat er met een andere blik naar het ziekteproces gekeken dient te worden en toekomstig onderzoek zal onder andere gericht dienen te zijn op het vinden van adequate en bruikbare anti-oxidanten.

\section{Behandelmogelijkheden en topreferente zorg}

Er zal gezocht moeten worden naar geneesmiddelen die de ontstane ontsporing van het afweersysteem kunnen herstellen. De ontwikkeling van nieuwe geneesmiddelen kost veel geld. Zodra nieuwe middelen beschikbaar zijn gekomen, is het niet altijd mogelijk ze voor te schrijven. Een voorbeeld hiervan is de kostbare anti-TNF-alfa therapie. Geneesmiddelen met een dergelijke werking hebben hun sporen al verdiend bij patiënten met bepaalde vormen van reuma en een darmziekte, de ziekte van Crohn. Al eerder heb ik aangegeven, dat het belangrijk is om patiënten met gecompliceerde chronische aandoeningen centraal te registreren en de behandeling centraal te laten aansturen. Dit mag echter niet betekenen dat het bewuste centrum, zoals het 
ild care centrum van het azM, verantwoordelijk wordt gesteld voor de volledige kosten van een dergelijke behandeling tenzij daar een apart budget voor beschikbaar wordt gesteld.

Een topreferent centrum moet niet alleen in staat zijn om de diagnose zo adequaat mogelijk te stellen, er dient ook gelegenheid te zijn voor het adviseren, voorschrijven en toepassen van de meest geschikte therapie. Vorig jaar is de budgetfinanciering vervangen door de zogenaamde Diagnose-Behandeling-Combinaties (DBCs). DBCs zijn zorgproducten geleverd door de onderneming: het ziekenhuis. In het huidige DBC-systeem is voorzien in de diagnostiek doch helaas is onvoldoende rekening gehouden met dure behandelmogelijkheden. Dure geneesmiddelen worden niet langer apart gefinancierd, maar behoren hier ook te worden ondergebracht.

De prijzen van nieuwe geneesmiddelen zullen per definitie hoog zijn. De kosten van het investeren in research zullen moeten worden terugverdiend. Nieuwe geneesmiddelen worden in de meerderheid der gevallen intramuraal ofwel in ziekenhuizen gelanceerd. Ziekenhuizen krijgen daarom vooral met de problematiek van hoge kosten en onduidelijkheid rond therapeutische en economische meerwaarde te maken. Dure geneesmiddelen zijn onvoldoende opgenomen in het vergoedingssysteem voor ziekenhuizen. Dit heeft in de praktijk nogal eens het gevolg dat artsen toestemming wordt geweigerd om dergelijke middelen voor te schrijven. Zo kunnen artsen hun zorgplicht niet optimaal vervullen. Bovendien is er nu een willekeur gecreëerd. De ene zorgverzekeraar is wel bereid tot vergoeding en de ander niet. Dat is maatschappelijk onacceptabel.

\section{Maatschappelijke consequenties}

Maatschappelijk dient bovendien een belangrijke afweging te worden gemaakt. Indien een chronisch zieke in staat is om aan het arbeidsproces deel te nemen met behulp van bepaalde geneesmiddelen, ook al zijn deze kostbaar, kan het zijn dat deze behandeling toch kostenbesparende gevolgen heeft. Dit is het 
geval wanneer de bewuste persoon geen beroep meer hoeft te doen op arbeidsongeschiktheidsvoorzieningen. Een goede kosten baten analyse zou hier op zijn plaats zijn. Dit vergt nauwe samenwerking tussen verschillende ministeries.

Onlangs kreeg ik het verzoek van de werkgever van een patiënt om aan te geven wat de meest optimale behandeling voor hun werknemer zou zijn. Tevens gaven ze aan onder bepaalde voorwaarden bereid te zijn tot vergoeding. Als reden werd opgegeven dat zij deze werknemer zo waardeerden dat ze er alles aan wilden doen om hem instaat te stellen zijn werkzaamheden te hervatten, zelfs als dat zou inhouden het bekostigen van op de dat moment nog niet door de zorgverzekeraar vergoede medicatie. Inderdaad zou een dergelijke behandeling netto wel eens kostenbesparend kunnen zijn, indien verschillende instanties bereid zijn de handen ineen te slaan en bijvoorbeeld de kosten voor de behandeling te delen.

\section{Zorgverlening en voorzieningen}

De complexiteit van de geneeskunde noodzaakt een steeds meer specialistische aanpak. Artsen worden min of meer gedwongen zich te beperken tot hun vakgebied. Een medisch specialist is iemand die wordt opgeleid tot het verwerpen van een diagnose op zijn/haar vakgebied. Vaak wordt geroepen: 'het is niet cardiaal, het is niet pulmonaal' en vervolgens wordt de patiënt vertwijfeld achtergelaten. Hier is sprake van een paradox. Er zijn steeds meer oplossingsmogelijkheden, de complexiteit van patiëntenproblemen neemt hierdoor alleen maar toe. Het gevolg is specialisatie. Dat betekent niet letterlijk dat de arts geen afdwaling kan of mag maken. Bovendien is kennis van elkaars kunnen en samenwerking nodig bij het interpreteren van bepaalde observaties.

Artsen zijn net een soort artiesten of kunstenaars. Een juiste dosis koppigheid, energie en bereidwilligheid om altijd weer de juiste samenwerking te zoeken zijn belangrijke eigenschappen. Integriteit is belangrijk. Op die manier kan interdisciplinaire sa- 
menwerking de patiëntenzorg en de wetenschap verbeteren. Het vinden van mensen die bereid zijn om er net een schepje boven op te doen ondanks de werkdruk zal hierbij inspirerend werken.

'Kan niet bestaat niet' heb ik al jong geleerd. Dat is iets wat ik mezelf altijd voor ogen heb gehouden bij het streven naar oplossingen, niet te snel opgeven. Hierbij moet je durven af te wijken van de norm, anders wordt de gezondheidszorg te star. Laat je niet in een bepaald vakje duwen, wees bereid je zogenaamde taak te overstijgen en mijdt de hokjesgeest. Tijdnood en productiedwang leiden tot minder kansen om te ontdekken wat er werkelijk speelt. Dit geldt bij uitstek voor gecompliceerde ziektebeelden, waaronder interstitiële longaandoeningen, waarvan de oorzaak niet altijd voor de hand liggend is. De begeleiding van deze specifieke groep patiënten door inhoudsdeskundigen kan bovendien onnodig veel kosten besparen aangezien dan sneller doorzien wordt wat het probleem is en sneller een advies op maat gegeven kan worden. In sommige gevallen kan een dergelijke aanpak onnodige diagnostiek voorkomen.

Om bepaalde diagnostische mogelijkheden te kunnen nalaten is kennis van het probleem noodzakelijk. Maar het heeft ook een keerzijde. Men dient zorgvuldig het integraal en generalistisch denken te blijven integreren in het specialistisch handelen en benaderen van iedere patiënt met een willekeurige hulpvraag.

\section{Verbetering van de zorgverlening}

Een 50-jarige patiënt presenteert zich met heftige pijn op de borst op de EHBO van een ziekenhuis. Vanwege de ernst van de presentatie wordt de cardioloog in eerste instantie om hulp gevraagd. Er wordt een ECG gemaakt en wat bloedonderzoek gedaan. Dit levert geen afwijkingen op en de cardioloog stelt de patiënt gerust, er is niets met het hart. Aangezien de patiënt aangeeft dat de klachten bij diep zuchten toenemen wordt de longarts in consult gevraagd. Een foto van de longen en aanvul- 
lend laboratoriumonderzoek levert niets verontrustends op en er wordt opnieuw geen verklaring gevonden voor de klachten. De patiënt krijgt pijnstillers mee en wordt geadviseerd contact te op te nemen met de huisarts als de klachten niet overgaan. Uiteindelijk wordt een gespecialiseerde fysiotherapeut, een manueel therapeut, om raad gevraagd. Deze stelt vast dat er sprake is van een klinisch relevante blokkade van een thoracaleofwel borstwervel. Wat was de hulpvraag? Is deze beantwoord? Hoe kan er sneller een adequate diagnose gesteld worden?

Het feit dat iedereen tegenwoordig met een bepaalde 'specialistische' bril naar de patiënt kijkt heeft een groot nadeel, namelijk dat de patiënt over het hoofd wordt gezien. De één bekijkt het hart, de volgende de longen, maar niemand kijkt naar het geheel. Dit maakt ook dat iemand uren op de EHBO kan doorbrengen zonder dat er een duidelijke conclusie wordt getrokken. Het enige dat er na uren lange evaluatie en wachten uit de bus komt is: 'als het niet over gaat kunt u toch het best naar de huisarts gaan.'

De geneeskunde heeft een enorme ontwikkeling doorgemaakt. Vele technieken zijn ontwikkeld om een diagnose te kunnen stellen. Eén van de belangrijkste eigenschappen van een goede clinicus blijft het kunnen onderscheiden van 'pluis' en 'niet pluis', ofwel wanneer het nodig is om verder te zoeken en wanneer de patiënt gerustgesteld kan worden (figuur 15). Helaas moeten we constateren dat het ook nu niet mogelijk is
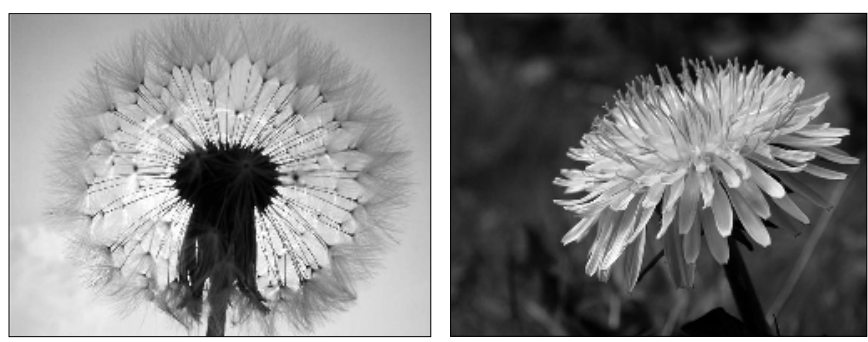

Figuur 15 - 'Pluis' of niet 'pluis', een belangrijke afweging voor een arts. 
alles te doorgronden. Soms moeten we toegeven dat we het niet kunnen vinden. Betekent dat dan dat er 'niets' aan de hand is of gewoonweg dat we met onze huidige mogelijkheden niet in staat zijn het te vinden? Ook nu geldt nog steeds: 'wat je niet kent herken je niet' en dus als je niet weet wat je zoekt vind je het niet. Of om met Johan Cruijff te spreken: 'Je gaat het pas zien als je het door hebt'.

\section{Evidence based medicine}

Evidence based medicine integreert vergaarde kennis uit onderzoek met de praktische ervaring van de clinicus. Dat laatste wordt opgebouwd door een dagelijkse nieuwsgierigheid naar het oplossen van vraagstukken en opdoen van ervaring. De vraag is bovendien of alle aspecten van het dagelijks (para)medisch handelen wel wetenschappelijk te onderzoeken zijn. De min of meer duidelijke gebieden zijn 'zwart' met bewijs dat iets niet zinvol of zelfs schadelijk is, of 'wit', met bewijs dat een behandeling de patiënt ten goede komt. Het gebied vol dilemma's is 'grijs'.

Medische specialisten krijgen patiënten verwezen via de huisarts naar een polikliniek of naar de spoedeisende hulp. Zij benaderen een probleem gewetensvol, expliciet en maken oordeelkundig gebruik van het huidig beschikbare bewijsmateriaal. In de praktijk betekent dit de integratie van klinische expertise en het beste externe bewijsmateriaal dat vanuit systematisch onderzoek beschikbaar is. Zij bekijken of het patroon van de aandoening hen bekend voorkomt. Wanneer een patroon niet duidelijk is, moet de arts zich afvragen of het gezondheidsprobleem van de patiënt tot zijn of haar specialisatie behoort en of hij of zij de meest competente professional is om dit gezondheidsprobleem aan te pakken.

Gezien het feit dat de arts de hoofdverantwoordelijke is bij het opstellen van zorgplannen voor de individuele patiënt, dient hij wat betreft de allround diagnostiek ook op de hoogte te zijn van de competenties van andere professionals in het 
netwerk waarbinnen hij functioneert. Dit geldt niet alleen voor medici, maar zeker ook voor competente paramedici, die door aanvullende scholing en/of klinische werkervaring op een academisch denk- en werkniveau acteren. Dit pleit, zowel in de therapie, maar zeker ook in de diagnostiek voor multidisciplinaire netwerken met een perfecte afstemming van de verschillende professionals, gebruik makend van ieders eigen competentie. De longarts als dé specialist van de longen, de cardioloog als dé specialist van het hart, de reumatoloog als dé specialist van inflammatoire aandoeningen, de neuroloog als dé specialist van het zenuwstelsel, de orthopeed als dé specialist van het houdings- en bewegingsapparaat qua statiek en operatieve technieken, de fysio/manueeltherapeut als dé specialist van het houdings- en bewegingsapparaat in functionele zin, etc. Daarom zou het goed zijn als aan het team van zorgverleners betrokken bij de eerste opvang van patiënten op de spoedeisende hulp en diverse poliklinieken ook een fysiotherapeut of manueeltherapeut zou worden toegevoegd. De toekomst vraagt om nog betere afstemming van de zorg op de hulpvraag binnen een nog steeds lerende organisatie.

\section{Richtlijnen in de praktijk}

In de geneeskunde is een goede dosis nieuwsgierigheid en creativiteit van essentieel belang. Uit te durven gaan van de aanname dat de verworven kennis wellicht niet toereikend is en dat verder zoeken een noodzaak is, wordt niet altijd gewaardeerd. Steeds meer wordt in de geneeskunde een soort kookboekenstijl gehanteerd. Richtlijnen zijn opgesteld om er een zo zorgvuldig en weloverwogen handelen mee te bereiken. Dat lijkt nobel, het gevaar is echter dat men niet meer zelf nadenkt en dat de creativiteit verloren gaat.

Ziektebeelden die gepaard gaan met interstitiële longafwijkingen zijn veelal zeldzaam en worden niet altijd direct herkend. Dit vergt uitgebreide diagnostiek en een belangrijke dosis creativiteit van de arts. 'Wanneer is het begonnen?', 'wat hebt u ge- 
daan?', 'waar hebt u allemaal contact mee gehad?' zijn vragen die uitermate zorgvuldig nagegaan dienen te worden. Vragen naar iemands beroep is niet voldoende. Blootstelling aan allerlei stoffen, werkomstandigheden, hobby's, omstandigheden thuis etc. ook in het verleden kunnen van groot belang zijn.

\section{Verbeteren en optimaliseren van voorzieningen}

Om de zorg te verbeteren en vergoeding voor nieuwe medicijnen te bewerkstelligen is samenwerking tussen patiëntenverenigingen, beroepsorganisaties en artsen van groot belang. Ook in dit geval geldt dat samenwerking kan leiden tot het bieden van een betere integrale zorg. Om gelden ook op ander terrein dan alleen onderzoekssubsidies te kunnen genereren is in Maastricht de 'ild care foundation' opgericht. Het doel van de zorg die wij artsen bieden dient aan te sluiten bij de vraag en behoefte van de patiënten. Het verzorgen van second-opinions en aanbieden van topreferente zorg schept verplichtingen. Deze service dient aan te sluiten bij de zorgvraag. Tevens is van belang de verwijzende collega's handreikingen te bieden met als doel gezamenlijk de begeleiding van patiënten met gecompliceerde aandoeningen te optimaliseren.

Door het benutten van de steeds groeiende digitale mogelijkheden zal nog winst behaald kunnen worden. De zogenaamde e-consulten zullen een steeds belangrijkere plaats in gaan nemen bij het fungeren als tertiair referentiecentrum. Nationale en internationale samenwerking kan hier optimaal benut worden en de kosten van de gezondheidszorg verder beperken.

\section{Rol van de overheid}

Longfibrose ofwel bindweefsel- of littekenvorming in de long kan tot een zeer ernstige adembenemende situatie leiden. Een goede behandeling met medicijnen is helaas niet voorhanden. Longtransplantatie kan bij deze patiënten soms het enige redmiddel zijn. Als mensen het geluk hebben om voor een transplantatie in aanmerking te komen kan dat hun leven 180 graden 
doen veranderen. Van niets kunnen ze weer normaal functioneren, sporten, etc. Ze kunnen weer actief betrokken zijn bij de opvoeding van hun kinderen en weer volledig deelnemen aan het arbeidsproces, nadat ze letterlijk nieuwe inspiratie hebben gekregen.

Dit brengt mij ook op een punt waar ik aandacht voor wil vragen. In Nederland is het zo, in tegenstelling tot in België, dat men zich als donor actief moet aanmelden. In België is men donor, tenzij daar bezwaar tegen is gemaakt. Dit heeft tot gevolg dat het donoraanbod in België hoger is dan in Nederland. Nadrukkelijk kan de overheid hier bijdragen de zorgvoorzieningen te optimaliseren. Maar wij, leden van de samenleving, dienen ons te realiseren wat het betekent om iemand een nieuwe kans te bieden en tegen iemand na een transplantatie weer te kunnen zeggen: 'leef!'

\section{Uitdaging}

Inspiratie, respect, motivatie, inzet, gedrevenheid en passie zijn eigenschappen die er toe doen.

Net dat beetje meer willen doen maakt het verschil. Daarmee komen we verder evenals met bereidheid tot samenwerking tussen verschillende disciplines, instituten en organisaties. Zo kunnen we een bijdrage leveren aan het verbeteren van de gezondheidszorg en verdiepen van de kennis.

\section{Onderwijs}

De afdeling longziekten participeert zeer gevarieerd in het curriculum geneeskunde en gezondheidswetenschappen en vervult allerlei rollen en functies. Hieraan zal een extra dimensie toegevoegd worden. Het aandachtsgebied interstitiële longaandoeningen (ild) verdient een zorgvuldige verdieping en meer centrale plaats binnen het vakgebied longziekten en daarbuiten. Binnen het basiscurriculum geneeskunde wordt reeds ruimschoots aandacht besteed aan het verbreden van de kennis van chronische aandoeningen in het algemeen. De kennis betref- 
fende ild dient hier een integraal deel van uit te gaan maken. Zo zal het aandachtsgebied ild onder een groot relevant medisch publiek worden verspreid. Om dit verder te bewerkstellingen zullen studenten aangemoedigd worden en actief geworven worden om een klinische keuzestage of een wetenschappelijke stage te volgen. Daarnaast wordt de gelegenheid geboden om een deel van de opleiding tot medisch specialist te volgen binnen het ild care centrum in het azM. Diverse opleidingen komen hiervoor in aanmerking. Het opleidingstraject wordt afgestemd met allerlei beroepsorganisaties met als belangrijkste doel de kennis op het terrein van ild bij zoveel mogelijk vakgebieden te verbreden en vergroten. Voor het bewerkstellingen van deze doelstelling zullen de volgende activiteiten worden voortgezet en verder ontplooid: 1) aanbieden keuzestages op de eerste plaats voor medische studenten van de universiteit Maastricht, maar ook van andere landelijke en internationale universiteiten en hogescholen, 2) participeren aan diverse specialistenopleidingen, hiervoor dienen nauwe contacten te worden gelegd met de diverse beroepsorganisaties, en 3) verzorgen van postgraduaat onderwijs zowel nationaal als internationaal.

Alle ingrediënten aan bod gekomen tijdens mijn betoog zijn van belang voor de ontwikkeling van goede zorgverleners, inclusief medici. Ik daag daarom studenten en arts-assistenten uit bij ons stage te komen lopen om samen met ons te trachten deze droom de komende jaren werkelijkheid te maken.

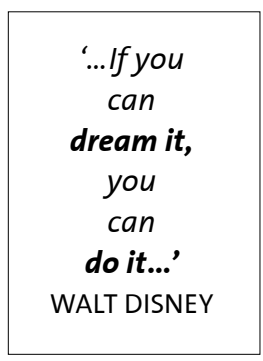




\section{Samenvatting}

Zoals al eerder aangegeven is het belangrijk bij het begeleiden van patiënten met interstitiële longaandoeningen dat je creatief bent en vooral geen genoegen neemt met het ontbreken van een verklaring. Blijven zoeken, je blijven afvragen hoe het kan en desnoods op huisbezoek gaan is van groot belang. Tijdens mijn opleiding tot fysiotherapeut heb ik integraal en holistisch leren denken, daar ondervind ik nog steeds veel plezier van. Als artsen hebben wij een prachtig vak. Wij zijn de detectives van de gezondheidszorg. Geduldig en bereid zijn - indien nodig - af te wijken van de gebruikelijke weg is essentieel. Blijven streven naar de juiste samenwerking, niet bang zijn voor 'wisselende contacten' dat kan namelijk leiden tot oplossingen waar je eerder niet aan zou hebben gedacht.

Specialisatie moet niet tot kokerdenken leiden, maar juist de kwaliteiten van generalistisch denken weten te benutten, blijven streven naar het vinden van verklaringen en oplossingen, je niet laten ontmoedigen door werkdruk. Het gaat namelijk om iets unieks: een medemens stelt zich kwetsbaar op, heeft een hulpvraag en het is onze taak deze zo zorgvuldig mogelijk te beantwoorden. De patiënt zal hierbij ook op zijn of haar eigen verantwoordelijkheid worden aangesproken. Ook al is er ogenschijnlijk geen oplossing dan nog kun je als zorgverlener laten merken dat je er bent en de patiënt het gevoel geven dat hij of zij er niet alleen voor staat.

Hier is ook een belangrijke rol weggelegd voor het verzorgen van onderwijs. Studenten en artsen in opleiding dienen enthousiast gemaakt te worden en erop gewezen te worden dat je niet te snel genoegen moet nemen met het ontbreken van een antwoord. Voor het vinden van een verklaring moet je soms ook denken aan onverwachte mogelijkheden. 
Het moge duidelijk zijn dat ik trots ben op mijn vak en mijn werk met volle inzet wil voortzetten gestimuleerd door de nieuwe kansen mij vandaag geboden.

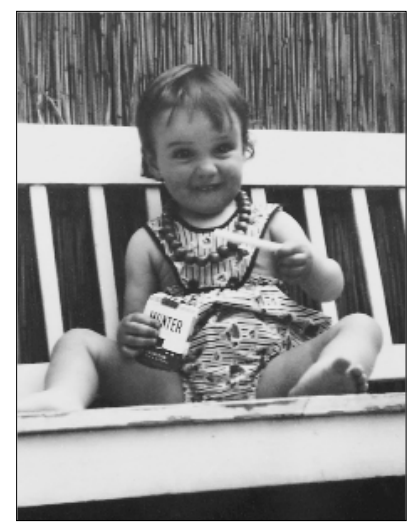

Figuur 16 - Longarts in spe (MD). 


\section{Dankwoord}

Mijn opleiders wil ik danken voor hun wijze lessen en het nog steeds geven van waardevolle adviezen. Overleggen blijft cruciaal. De afgelopen jaren heb ik ontdekt dat in het azM en binnen de UM enorm veel enthousiaste mensen werken die bereid zijn de schouders eronder te zetten. De medewerkers van bijna alle medische vakgroepen hebben bewezen dat multidisciplinaire samenwerking in het azM prima kan, daarvoor hartelijk dank. In het bijzonder wil ik de leden van het sarcoïdose management team heel hartelijk danken!

Contacten tussen basiswetenschappers en allerlei ondersteunende disciplines zoals de afdeling radiologie, pathologie, klinische chemie, hematologie, elektronen microscopie, medische microbiologie, farmacologie en toxicologie hebben menigmaal geleid tot waardevolle discussies en hebben uiteindelijk kunnen bijdragen tot het oplossen van klinische problemen. Daarvoor hartelijk dank! Ook alle betrokkenen buiten het azM en de UM die hebben bijgedragen bij het tot stand komen van de inspiererende leerstoel interstitiële longaandoeningen ben ik zeer erkentelijk.

Mijn promovendi Ruth, Nicolle, Els, Snjezana en Elske dank ik voor jullie doorzettingsvermogen en bijdrage aan het onderzoek. Agnes, Judith en Gwan zet hem op!

Professor Miel Wouters, duizendpoot, onder andere afdelingshoofd van de afdeling longziekten en de initiatiefnemer voor het centrum voor chronische ziekten, mijn collega's, assistenten, longfunctieassistenten, medewerkers van de afdeling klinische neurofysiologie, verpleging, poliassistenten, secretaresses, en de studiebegeleiders Ester en Gé, wil ik bedanken. De medewerkers van de AV-dienst en dienst automatisering waren op sommige momenten onmisbaar.

Een belangrijke ontwikkeling waar ik graag even bij stil wil staan is de steun voor de onderzoekslijn interstitiële longziekten van de raad van bestuur van het azM in het bijzonder de voorzitter drs. Guy Peeters en de faculteit van de UM vooral de 
decaan van de faculteit der geneeskunde, prof.dr. Harry Hillen. Dat maakt dat het ild care centrum vanuit het azM een service kan bieden gedragen door een brede basis. Daar ben ik ook alle andere betrokken vertegenwoordigers zeer erkentelijk voor.

Dear international colleagues, dear mentors, dear friends, it is a great honour and pleasure that you are present today and did not hesitate to travel to Maastricht. I appreciate this very much. Without your support and challenging discussions I would not stand here today.

De patiënten die al die jaren vertrouwen hebben gesteld in onze aanpak en ook steeds weer bereid waren om met allerlei onderzoeken mee te doen, wil ik hartelijk danken. Ook hier geldt bij uitstek samen komen we veel verder!

Mijn moeder, mijn vader, mijn zus jullie zijn trots op mij, maar ik ben trots op jou mama omdat jij voor de basis van mijn opleiding garant hebt gestaan en er altijd voor ons was, papa aangezien je me hebt gestimuleerd te vechten voor wat ik wilde en Sylvia, omdat ondanks dat je mijn kleine zusje was, uitgegroeid bent tot een heel sterke zelfstandige vrouw. Oma, jou dank ik eeuwig, jij weet wel waarom...

Marjon, je hebt mijn hele ontwikkeling meegemaakt en gestimuleerd. Ook na vandaag zal ik jou steun hard en hard nodig hebben. Ons beider inspiratie zal hopelijk nog tot vele nieuwe adembenemende contacten leiden.

Ik heb gezegd. 


\section{Appendix}

\section{Relevante websites}

Waardevolle website met informatie over allerlei door medicijnen veroorzaakte ofwel drug-induced longziekten www.pneumotox.com

Health\&DNA. Allerlei informatie en software behulpzaam bij het veilig voorschrijven van geneesmiddelen. Drug-drug and drug-gene interaction software www.genemedrx.com

Belangenvereniging longfibrosepatiënten Nederland www.longfibrose.nl

Sarcoïdose Belangenvereniging Nederland (SBN) www.sarcoidose.nl

World association of sarcoidosis and other granulomatous diseases (WASOG) wWw.pinali.unipd.it/sarcoid/

Afdeling longziekten azM, Maastricht www.pul.unimaas.nl

Het ild care centrum azM en de ild care foundation www.ildcare.eu 
De ild care foundation (interstitiële longaandoeningen inclusief sarcoïdose en beroeps- en omgevingsgerelateerde longaandoeningen management en research foundation) stelt zich ten doel de zorg voor patiënten met interstitiële longaandoeningen te optimaliseren. Er zal gestreefd worden naar verbreding van de kennis, het ondersteunen van onderzoek en verbetering van de therapeutische mogelijkheden van interstitiële longaandoeningen.

Bijdragen ter ondersteuning van de foundation worden in dank aanvaard.

Deze kunt u overmaken op bankrekeningnummer: 65.34.34.642 t.n.v. ild care foundation, o.v.v. uw naam en e-mail nummer.

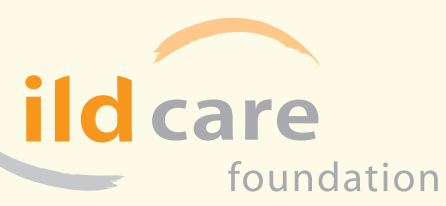

